\title{
ÉRVEK A KVANTUMFIZIKA EVERETT-FÉLE SOKVILÁG-INTERPRETÁCIÓJA MELLETT
}

\author{
Pszota Gábor \\ egyetemi docens, Miskolci Egyetem, Fizikai és Elektrotechnikai Intézet, Fizikai Tanszék \\ 3515 Miskolc, Miskolc-Egyetemváros, e-mail: fizpszo@ uni-miskolc.hu
}

\begin{abstract}
Absztrakt
A mikroszkopikus rendszerek leírására a kvantumfizika nagyon sikeresnek bizonyult. Ennek lényege, hogy a rendszert egy állapotfüggvény (hullámfüggvény) írja le, a fizikai mennyiséget pedig operátorral feleltetik meg. Ezeknek az operátoroknak a sajátértékei adják meg a mérés lehetséges értékeit és az ezekhez tartozó sajátállapotokat, továbbá a számitások során megkapjuk a különbözö lehetőségek valószinüségeit is. A kvantumfizika eredeti interpretációja szerint a mérés elvégzésekor a sok lehetöség közül csak az egyik realizálódik, vagyis az eredeti állapotfüggvény összeomlik a megvalósuló sajátállapotba. Ezzel az elképzeléssel több elvi probléma is adódik, ezért aztán az utóbbi évtizedekben egyre népszerübbé vált a sokvilág-interpretáció, amely szerint mindegyik lehetöség egyformán valódinak tekintendö. A matematikai formalizmust tekintve a két elképzelés megegyezik, különbség mindössze az eredmények értelmezésében van. Egyértelmü kisérleti bizonyiték tehát nehezen szerezhetö, de ez mégsem lehetetlen. Számos érv van a sokvilág-interpretáció mellet, különösképpen ilyen a müködö kvantumszámítógép létezése. A jelen cikk célja, hogy egyfajta hiánypótlásként ezeket a modern eredményeket és elveket magyar nyelven összefoglalja, kiegészitve azokat néhány érdekességgel.
\end{abstract}

Kulcsszavak: kvantumfizika, Everett-féle sokvilág-interpretáció, relativ állapotok, mérési folyamat

\begin{abstract}
Quantum physics turned out to be very successful in describing microscopic systems. The essence of this is that the system is described by a state function (wave function) and the physical quantity is represented by an operator. The eigenvalues of these operators give the possible values of the measurement and the corresponding eigenstates, and we also get the probabilities of the different possibilities from the calculations. According to the original interpretation of quantum physics, when a measurement is performed, only one of the many possibilities is realized, i.e. the original state function collapses into the realized eigenstate. There are several theoretical problems with this idea, so the many-worlds interpretation, according to which all possibilities should be considered equally real, has become increasingly popular in recent decades. In terms of mathematical formalism, the two ideas are the same, the only difference being in the interpretation of the results. Clear experimental evidence is therefore difficult to obtain, but it is not impossible. There are numerous arguments in favor of the multi-worlds interpretation, most notably the existence of a functioning quantum computer. The aim of this article is to summarize these modern results and principles in Hungarian, kind of filling in the gaps, and supplementing them with some interesting facts.
\end{abstract}

Keywords: Quantum physics, Everett's many-worlds interpretation, relative states, measurement process 


\section{Bevezetés}

A mikroszkopikus rendszerekre jellemző fizikai tulajdonságok mérésekor azt tapasztalták, hogy azok eltérnek a klasszikus fizikában megszokott törvényszerüségektől. Például az atomok energiaszintjeinek, vagy a molekulákban lévő atomok egymáshoz képesti rezgésének energiája kizárólag diszkrét értékeket vehet fel. Ha egy körpályán keringő kötött rendszert vizsgálunk, pl. a Nap és Föld viszonyát nézzük, akkor a rendszer mechanikai energiája $(E=T+V)$ nyugvó Napot feltételezve:

$$
E=-\frac{\gamma M m}{2 r}
$$

ahol $\gamma=6,67 \cdot 10^{-11} \frac{\mathrm{Nm}^{2}}{\mathrm{~kg}^{2}}$ a gravitációs állandó, $M$ a Nap tömege, $m$ a Föld tömege, $r$ pedig a körpálya sugara. Ez az energia tehát folytonosan változhat a körpálya sugarának függvényében. Ezzel szemben, ha egy hidrogénszerü iont vizsgálunk, tehát egy $Z$ számú protont tartalmazó nyugvó atommag körül keringő elektronról van szó, akkor ez az energia diszkrét értékeket vehet csak fel [1], vagyis azt mondhatjuk, hogy az energia kvantált:

$$
E_{n}=-\frac{E^{*} Z^{2}}{n^{2}}
$$

ahol $E^{*}=2,18 \cdot 10^{-18} \mathrm{~J}, n$ egy pozitív egész szám és $Z$ a rendszám. Amennyiben a $Z=1$ és $n=1$ feltétel egyaránt teljesül, akkor a hidrogénatom alapállapoti energiáját kapjuk, vagy ha a pozitív értéket nézzük, akkor a hidrogén $E^{*}$ ionizációs energiáját. Az atomok vonalas színképe ezen energiaszintek közötti különbségekről árulkodik.

A másik példa erre a kettőségre, ha egy rúgóhoz rögzített test harmonikus rezgőmozgását hasonlítjuk össze egy mikroszkopikus rendszerrel, pl. egy molekulában található két atom által alkotott oszcillátorral. Ekkor a mechanikai energia a két rendszerre a következö:

$$
E=\frac{1}{2} m v^{2}+\frac{1}{2} D x^{2}, \quad E_{n}=h f\left(n+\frac{1}{2}\right),
$$

ahol $m$ a test tömege, $v$ a sebessége, $D$ a rúgóállandó és $x$ az egyensúlyi pozíciótól mért kitérés, illetve $h=6,63 \cdot 10^{-34}$ Js a Planck állandó, $f$ a rezgés frekvenciája, és $n$ egy természetes szám. A különbözö molekulák vonalas színképei itt is kísérleti bizonyítékot szolgáltatnak a diszkrét energiaszintekre. Az ilyen stacionárius állapotok között nem lehetséges folytonos átmenet, hanem a rendszer ugrásszerüen megy át egyik állapotból a másikba, miközben a kisugárzott vagy elnyelt energia a $h f$ energiakvantumok egész számú többszöröse. Ez a feltételezés elengedhetetlen volt például Planck számára [2], hogy a hőmérsékleti sugárzás színképét le tudja elméleti úton vezetni.

Szükség volt tehát egy olyan matematikai tárgyalásmódra, amely helyesen írja le a mikrovilág állapotait és folyamatait, vagyis bizonyos esetekben a fizikai mennyiségekre diszkrét értékeket ad eredményül. Határesetben viszont vissza kell kapnunk a klasszikus fizika törvényeit, ezt nevezik korrespondencia elvnek. Jól látható, hogy a (2) és (3) egyenletekben nagy $n$-ek esetében az energiaszintek közötti különbség arányában elhanyagolhatóvá válik az adott szintek energiájához képest, tehát a követelmény ezeknél a példáknál teljesül. Már itt látható azonban egy jelentős különbség a klasszikus és a kvantumfizikai eredmények között, ugyanis a (3) egyenletben a jobb oldali energia nem lehet nulla az oszcillátor esetében. Ezt zérusponti energiának nevezik.

A felismerés az volt, hogy a klasszikus fizikában szereplő folytonos függvények helyett a fizikai mennyiségekhez ezúttal operátorokat kell rendelni, amelyek diszkrét sajátértékekkel is rendelkezhetnek, 
és ezek az értékek mindig valósak. Emiatt az operátoroknak hermitikusnak [1] kell lenniük. Ezen operátorok sajátértékei adják meg a fizikai mennyiségek mérésekkel megállapítható lehetséges értékeit. Az operátorok olyan müveletek, amelyek egy függvényhez egy másik függvényt rendelnek. Ez lehet például valamelyik koordinátával való szorzás, vagy valamelyik koordináta szerinti deriválás. Az $x$ koordináta operátora pl. az $x$-el való szorzás, az $x$ irányú lendület operátora pedig $i \frac{\partial}{\partial x}$. Az egyéb fizikai mennyiségek operátorai az alapmennyiségekből származtathatók. Amennyiben $\lambda$ az $\boldsymbol{O}$ operátor sajátértéke $\psi$ pedig az operátor sajátfüggvénye, akkor teljesül a következö egyenlet:

$$
\boldsymbol{O} \psi=\lambda \psi,
$$

tehát a sajátfüggvényen a hermitikus operátor hatása mindössze egy valós számmal való szorzás. Ha az $\boldsymbol{O}$ operátor az energia operátora, akkor az időtől független Schrödinger egyenletet kapjuk, és ez megadja a rendszer lehetséges energiaszintjeit és az ezeknek megfelelő sajátfüggvényeket. Ezen sajátfüggvényeknek egyértékủnek, folytonosnak és négyzetesen integrálhatónak kell lenniük, hogy fizikai jelentéssel bírjanak [1]. Utóbbira azért van szükség, hogy a belső szorzat nevü mủveletet el lehessen végezni a $\psi$ függvényeken:

$$
(\psi, \psi)=\int \psi^{*} \psi d V=1,
$$

ahol az integrálás a rendszer teljes térfogatára értendő, $\psi^{*}$ a komplex konjugált, az 1 eredmény pedig azt jelenti, hogy a rendszer lehetséges állapotait 1-re normált függvényekkel írjuk le. Ezek a függvények, a tulajdonságaikat tekintve egyfajta vektoroknak tekinthetők az elvileg végtelen, de legalábbis szinte elképzelhetetlenül nagyszámú dimenzióval rendelkező Hilbert térben. Az állapotfüggvények ugyanis már néhány részecskéből álló rendszer esetén is óriási számú dimenzióval rendelkező vektorok, hiszen a részecskék közötti kölcsönhatás miatt több rendszer egyesítésekor a dimenziók száma nem összeadódik, hanem összeszorzódik. A rendszer $\Psi$ állapotfüggvénye (vagy hullámfüggvénye) általában nem valamelyik sajátállapot. Ez a $\Psi$ függvény tartalmaz minden információt, amely a rendszerről tetszőleges mérések végrehajtásával megismerhető. Amennyiben a hermitikus operátor sajátértékei diszkrétek, akkor a sajátfüggvények teljes ortogonális függvényrendszert alkotnak, tehát ennek a bázisnak a segítségével az eredeti állapotfüggvény sorbafejthető:

$$
\Psi=a_{1} \psi_{1}+a_{2} \psi_{2}+\cdots+a_{n} \psi_{n}
$$

ahol az $a_{i}$ szorzók komplex számok. Ennek a Neumann János által bebizonyított tételnek nagy jelentősége van, ugyanis végeredményben azt mondja ki, hogy minden egyes mérés esetében, amennyiben a lehetséges értékek száma véges, az eredeti állapot sorbafejthető a különböző mérési eredményeknek megfelelő sajátállapotokkal, amelyek meghatározott valószínüségekkel következnek be. A kvantumfizikai rendszer tulajdonsága ugyanis az, hogy ha a rendszer nincs az adott mérésnek megfelelő valamely sajátállapotban, tehát az nem olyan, mint pl. egy alapállapotban lévő hidrogénatom, akkor a mérés tényleges eredményéről mindössze valószínüségeket tudunk mondani, illetve kiszámolható egy várható érték. Ez nem feltétlenül lesz a ténylegesen mérhető értékek valamelyike, hiszen ez mindössze egy valószínüségekkel súlyozott átlag:

$$
\begin{aligned}
\bar{O}=(\Psi, \boldsymbol{O} \Psi) & =\int \Psi^{*} \boldsymbol{O} \Psi d V=\sum_{k=1}^{n} \int a_{k}{ }^{*} \psi_{k}{ }^{*} \lambda_{k} a_{k} \psi_{k} d V=\sum_{k=1}^{n} \lambda_{k} a_{k}{ }^{*} a_{k} \int \psi_{k}{ }^{*} \psi_{k} d V \\
& =\sum_{k=1}^{n} \lambda_{k} a_{k}{ }^{*} a_{k},
\end{aligned}
$$


ahol felhasználtuk, hogy az állapotfüggvény és a sajátfüggvények mindegyike egyre normált, tehát a belső szorzatukat képezve 1-et kapunk. Az is látható a végeredményből, hogy az egyes mérési eredmények bekövetkezési valószínüségét az $a_{k}{ }^{*} a_{k}=\left|a_{k}\right|^{2}$ mennyiségek adják meg, melyek összege 1 .

A $\Psi$ állapotfüggvény az időnek folytonos függvénye, időbeli fejlődését az időtől függő Schrödinger egyenlet írja le:

$$
\frac{\hbar}{i} \frac{\partial \Psi}{\partial t}+\boldsymbol{H} \Psi=0
$$

ahol $\boldsymbol{H}$ a Hamilton-operátor, amely pl. konzervatív erőtérben mozgó részecske esetében a teljes mechanikai energiának megfelelő operátor.

Érdemes még szót ejteni egyetlen részecske $\Psi$ állapotfüggvényéről. Ekkor $\Psi$ a koordináták és az idő folytonos függvénye, és a $\Psi^{*} \Psi d V$ kifejezés annak valószínüségét adja meg, hogy a részecske a $d V$ térfogatban található. Természetesen az 1-re normált $\Psi$ miatt a teljes térre vett integrál most is 1-el egyenlö, tehát a részecske valahol mindenképpen megtalálható. Amennyiben a tömegpont szabadon mozog, tehát a potenciális energia nulla, akkor a (7) egyenlet a $\Psi$ állapotfüggvényre síkhullámot ad megoldásul [1], amelynek hullámhossza a de Broglie hullámhossz: $\lambda=h / p$. Így aztán mindjárt érthető, hogy a részecske tényleges pozíciójáról a mérés végrehajtása előtt nem rendelkezünk pontos információval. Ezt a hullámtulajdonságot bizonyította Davisson és Germer [3] 1927-ben, amikor elektronnyalábot bocsátottak vékony fémfóliára és figyelték a kristályrács által létrehozott interferenciaképet. A kvantumfizikai tárgyalásmódból az is következik, hogy a részecske helye és lendülete nem mérhetö meg egyszerre tetszőleges pontossággal. Ez a Heisenberg-féle határozatlansági reláció, és az olyan fizikai mennyiségekre teljesül, amelyek operátorai nem cserélhetők fel egymással. Ilyen operátorok még az energia és az idő, valamint a perdület és az elfordulás szöge. A természetben tehát nem létezik olyan állapot, amelyben minden mennyiségnek egyszerre jól meghatározott értéke lenne, egy állapot nem lehet egyszerre minden operátornak sajátállapota.

\section{A mérési folyamat problematikája}

Tehát amennyiben a rendszer nincs az adott mérendő mennyiségre nézve valamelyik sajátállapotban, akkor a mérés a lehetséges sajátértékek egyikét fogja eredményezni, a mérés folyamata során létrejövő kölcsönhatás pedig a rendszert átviszi a mért értéknek megfelelő sajátállapotba. Azt, hogy melyikbe, lehetetlen előre megmondani, mindössze az egyes sajátértékek és a nekik megfelelő sajátállapotok valószínűsége számolható ki. Tehát a mérés előtt véges vagy esetleg végtelen számú különböző érték és sajátállapot lehetséges, azonban mégis csak egyetlen egy valósul meg ezek közül. Erre mondják, hogy a mérés a hullámfüggvény összeomlásával jár [4], és ez az eredeti, ún. koppenhágai interpretációja a kvantumfizikának, amellyel a manapság használt relatíve modern tankönyvekben $[1,5]$ is találkozhatunk.

Ez a folyamat nagyon jól megfigyelhető akkor, amikor csak két különböző sajátállapot lehetséges. Így történt akkor, amikor Stern és Gerlach [5,6] felhevített ezüst atomokból álló nyalábot vezetett át inhomogén mágneses téren, amely eltérítette azokat, mielőtt egy ernyőre vetültek volna. Az ernyőn a véletlenszerủ orientációjú atomi spinnek megfelelően folytonos eloszlást vártak, ezzel szemben mindössze két fényes folt jelent meg a $z$ irányba mérhető $\pm \hbar / 2$ sajátértékek miatt. A mágneses teret 90 fokkal elfordítva egy y irányba haladó nyalábnál az $x$ irány esetén is csak ugyanez a két sajátérték lehetséges. A kvantumfizika törvényeinek megfelelően, ha pl. az $\mathrm{S}_{z}-$ nyalábot kitakarják, és egy újabb $z$ irányú $\mathrm{SG}$ elrendezésen vezetik át a megmaradt $S_{z}+$ nyalábot, akkor nem lesz újbóli kettéválás [5]. Ez várható is, hiszen az atomok immár mind az $\mathrm{S}_{\mathrm{z}}+$ sajátállapotba kerültek. Ha viszont a második SG elrendezés $x$ 
irányú inhomogén teret hoz létre, akkor a megmaradt nyaláb ismételten kettéoszlik az $\mathrm{S}_{\mathrm{x}}+$ és $\mathrm{S}_{\mathrm{x}}-$ sajátállapotoknak megfelelően. Ez azzal magyarázható, hogy a megmaradt $S_{z}+$ nyaláb az $x$ irányú mérésnek nem sajátállapota, tehát mindkét $x$ irányú sajátállapot megjelenik. A kísérlet akkor válik még érdeksebbé, ha egy harmadik SG elrendezést is beiktatnak, ismételten a $z$ irányban, és kitakarják az $\mathrm{S}_{\mathrm{x}}-$ sajátállapotnak megfelelő nyalábot a második SG elrendezés után. A tapasztalat az, hogy a nyaláb ismét kettéválik az $\mathrm{S}_{\mathrm{z}}$ - és $\mathrm{S}_{\mathrm{z}}+$ sajátállapotoknak megfelelően. Tehát sorba véve az állapotfüggvény átalakulásait azt látjuk, hogy az egyik sajátállapotba összeomlott állapotfüggvény egy nem felcserélhető operátornak megfelelö mérés elvégzésével úgymond visszaépíthető, és újra tartalmazni fogja mindkét sajátállapotot. Ez felettébb furcsa.

Hasonló furcsaság figyelhető meg, ha egyszerre egyetlen fotont vagy egyetlen elektron engedünk rá egy kettősrésre, és így próbálunk meg interferenciaképet létrehozni [4]. Az interferencia jelenség mindaddig fennáll, amíg nem helyezünk el egy detektort az egyik réshez. Amennyiben a detektor információt nyújt arról, hogy a részecske melyik résen haladt keresztül - még akkor is, ha ez egy negatív mérési eredmény, tehát a részecske nem hat kölcsön a detektorral - a hullámtulajdonság és vele együtt az interferencia jelensége megszünik, tehát a hullámfüggvény összeomlik. Ez még talán megmagyarázható azzal, hogy a közelben elhelyezett detektor valamilyen módon mégiscsak hatást fejt ki a másik résen áthaladó elektronra. Elvégezhető azonban egy különböző kísérlet is [4], amely során elektronokat lőnek egymás felé egy vákuumkamrában, és azok egymáson szóródva teljes mértékben meghatározatlan irányokba haladnak tovább, mindketten hullámszerü tulajdonságot mutatva. A lendületmegmaradás törvénye miatt azonban a két elektronnak ellentétes irányba kell repülnie, tehát ha az egyik elektront egy detektorral megmérjük, akkor a kettő közötti távolságtól függetlenül a másik elektron iránya és sebessége is ismert lesz, vagyis a hullámfüggvénye azonnal összeomlik. Két ilyen részecske kapcsolata a kvantum összefonódás jelensége. Felmerül a kérdés, hogy mi okozza a hullámfüggvénynek ezt az öszszeomlását és az információ látszólag fénysebességnél gyorsabban való terjedését.

A kvantumfizika klasszikus elképzelése szerint tehát a hullámfüggvény kétféle folyamaton mehet keresztül [7, 8]:

1-es folyamat: Nem folytonos változás, amelyet egy $\psi_{1}, \psi_{2}, \ldots$, sajátállapotokkal rendelkező menynyiség mérésének folyamata vált ki, és ennek során a $\Psi$ állapotfüggvény a $\psi_{k}$ sajátállapotba ugrik $\left|\left(\Psi, \psi_{k}\right)\right|^{2}$ valószínüséggel.

2-es folyamat: Az elszigetelt rendszer állapotának folytonos, determinisztikus változása az idő függvényében a (7) időtől függő Schrödinger egyenlet szerint.

Könnyen el lehet azonban képzelni olyan szituációt, amely nem illeszkedik erre a matematikai formalizmusra. Vegyünk például egy olyan elszigetelt összetett rendszert, amely egy részecskékből álló rendszert és egy megfigyelöt vagy méröeszközt tartalmaz. Le tudja írni ennek a zárt rendszernek az időbeli változását a 2-es folyamat? Amennyiben igen, akkor úgy tünik nincs mód a nem folytonos 1-es folyamat megvalósulására, pedig a zárt rendszerben tartózkodó megfigyelő végezhet méréseket a részecskékből álló rendszeren. Ha nem, akkor azt kell mondanunk, hogy a megfigyelőket vagy mérömüszereket tartalmazó rendszerekre nem érvényes a minden más rendszerre elfogadott kvantumfizikai tárgyalásmód. A probléma különösen súlyossá válik, ha az elszigetelt rendszerünk maga a zárt univerzum. Ezen a rendszeren ugyanis nem lehet kívülről mérést végrehajtani független megfigyelőként. Nincs semmi olyan külső hatás, amely átmenetet okozna kívülről egyik állapotból a másikba. 


\section{A kvantumfizika Everett-féle interpretációja}

Az Everett-féle interpretáció [7, 8] lényege, hogy magát a 2-es folyamatot, tehát az időtől függő Schrödinger egyenletet tekinti teljes elméletnek. A központi posztulátum, hogy ennek a lineáris hullámegyenletnek mindenhol és minden időpillanatban eleget tevő hullámfüggvény kivétel nélkül minden zárt rendszer esetében teljes matematikai modellt biztosít. További posztulátum, hogy minden olyan rendszer, amely külső megfigyelésnek van kitéve, tekinthető úgy, mint egy nagyobb zárt rendszer része, amelynek szintén része a mérést végző megfigyelö vagy mérőmüszer. Ez a posztulátum teljesen logikusnak tủnik, hiszen az emberek és mérőmüszerek ugyanúgy atomokból álló fizikai rendszerek, mint bármely más rendszer, így aztán miért ne vonatkoznának rájuk ugyanazok a törvényszerüségek? A hullámfüggvényt az elmélet alapvető fizikai entitásként kezeli, annak előzetes interpretációja nélkül. A matematikai tárgyalásmód az állapotok relativitásához vezet a következő értelemben: egy összetett rendszer alrendszeréről nem lehet azt mondani, hogy egy jól meghatározott állapotban van függetlenül az összetett rendszer maradék részétől. Egy alrendszer bármely állapotához tartozni fog egy relatív állapot az összetett rendszer maradék részére nézve. Tehát az alrendszer állapota nem létezhet függetlenül, hanem azt meghatározza az összetett rendszer maradék részének állapota. Ez azt jelenti, hogy az alrendszerek állapotai nem függetlenek, hanem korrelációban vannak egymással. Ez a korreláció akkor jön létre a rendszerek között, amikor azok kölcsönhatnak egymással. Az Everett-féle tárgyalásmódban a megfigyelések és mérések ilyen kölcsönhatásoknak tekintendők. Ha tehát az $S$ összetett rendszer az $S_{1}$ és $S_{2}$ alrendszerekből áll, akkor az $S$ rendszer általános állapotfüggvénye kifejezhető az alrendszerek állapotfüggvényeinek lineáris szuperpozíciójaként:

$$
\Psi^{S}=\sum_{k, l} a_{k l} \psi_{k}^{S 1} \phi_{l}^{S 2},
$$

ahol a különböző $\psi_{k}{ }^{S 1}$ és $\phi_{l}^{S 2}$ állapotfüggvények teljes ortonormált halmazokat alkotnak az $S_{1}$ és $S_{2}$ rendszerekre nézve. Ekkor az egyik rendszer tetszőleges állapotának kiválasztásával egyértelmúen ki tudunk fejezni egy relatív állapotot a másik rendszerre a következő módon:

$$
\Psi\left(S_{2} ; \operatorname{rel} \psi_{m}, S_{1}\right)=N_{m} \sum_{l} a_{m l} \phi_{l}{ }^{S 2},
$$

ahol $N_{m}$ egy normalizációs konstans. Ezt a relatív állapotot a $\psi_{m}$ állapot egyértelmüen meghatározza. Ez azt jelenti, hogy a mérés pillanatában a mért rendszer lehetséges sajátállapotaihoz egyértelmüen tartozni fog a mérőmüszernek egy megfelelő sajátállapota. A nem folytonos ugrás az egyik sajátállapotba (1-es folyamat) tehát csak látszólagos relatív felvetés, hiszen minden lehetséges sajátállapothoz tartozik egy relatív állapot a mérőmüszer vagy megfigyelő részéről, és a szuperpozíció minden ilyen eleme egyszerre létezik. A teljes $S$ rendszerre nézve ez a folyamat folytonos. Ahhoz, hogy azt mondjuk, hogy egy $M$ megfigyelő megfigyelte az $\alpha$ eseményt, az $M$ megfigyelő eredeti állapotának meg kell változnia egy $\alpha$-tól függő állapotra. Ez okozhatja például egy mérőmüszer memóriájának vagy egy hús-vér megfigyelő memóriájának megváltozását, amely korrelációban lesz pl. a mérés során kapott értékkel, és a mért rendszernek az ahhoz tartozó sajátállapotával. A müszer vagy a mérést végző ember viselkedése tehát befolyásolva lesz a mérés eredménye által. Ha egy megfigyelő egymás után méréseket végez az A, B, C, D rendszereken, mely mérések lehetséges eredményei az egyszerüség kedvéért a $0,1,2,3$ számok lehetnek, akkor a megfigyelő egyik lehetséges memóriakonfigurációját az 1. ábra mutatja. Ez azonban csak egy a megvalósuló memóriakonfigurációk közül, ugyanis az Everett-féle interpretáció szerint az egyes mérések elvégzésekor a szuperpozíció minden eleme megvalósul, tehát a mérhető értékek minden lehetséges sorozata egyaránt valós. Ez úgy értelmezhető, hogy a megfigyelő az események többféle sorozatát tapasztalja meg, de természetesen egyszerre csak az egyik lehetséges sorozatnak lesz 
tudatában. Minden egyes mérés végrehajtásakor a megfigyelt rendszer látszólag beugrik a mért értéknek megfelelő sajátállapotba a megfigyelő szempontjából, de minden egyes sajátállapothoz tartozni fog a megfigyelőnek egy relatív állapota. Így bár a folyamat során a megfigyelő végig egyetlen fizikai rendszert képez, annak állapotáról nem mondható el, hogy egyetlen meghatározott sajátállapot lenne, hiszen minden mérés végrehajtásakor az eredeti állapot szerteágazik, esetünkben négy különböző állapotra. Az egyes ágak a mérés egy különböző kimenetelének felelnek meg, és a megfigyelt rendszer egy annak megfelelő sajátállapotának. Mindegyik ág egyszerre létezik egy szuperpozíció formájában a megfigyelések tetszőleges sorozata után. A többi ág, vagyis az eredmények többi lehetséges sorozata alternatív idővonalakon egy párhuzamos valóságként fogható fel, és innen ered a sokvilág-interpretáció elnevezés. A megfigyelő memóriakonfigurációja tehát az idő múlásával és a mérések végrehajtásával egy folyamatosan szerteágazó pályát fog követni, de természetesen semmiféle kettéválási folyamatnak nem lesz tudatában, hiszen a különböző ágak általában rohamosan nagyon eltérővé válnak, és a közöttük lévő kölcsönhatás gyorsan megszünik.
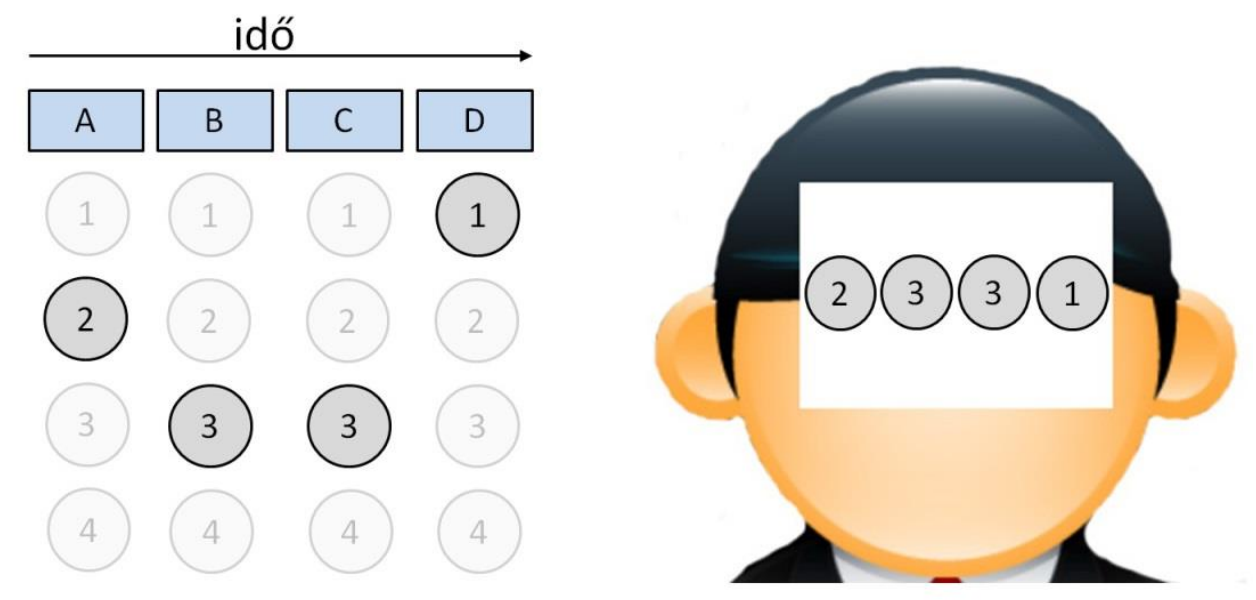

\section{1. ábra. Megfigyelö egy lehetséges memóriakonfigurációja a négy mérés végrehajtása után}

Ezt a folyamatot, melynek során az egymással inkonzisztens mintázatok egyre kisebb hatást fejtenek ki egymásra, dekoherenciának nevezik [4]. A dekoherencia hatékony magyarázatot tud adni a hullámfüggvény összeomlására, vagyis annak látszólagos összeomlására. Az elmélet segítségével ki lehet számolni annak időskáláját, hogy az adott rendszer esetében dekoherencia lépjen fel, vagyis a régi elgondolás szerint, bekövetkezzen a hullámfüggvény összeomlása [9]. A szituáció egy apró test lokalizációjával kapcsolatos, amelynek pozícióját időről-időre meghatározza a környezetében lévő fotonokkal és egyéb részecskékkel való kölcsönhatás. Az 1-es táblázat ezeket az időskálákat tartalmazza [9].

A bal felső szám például azt jelenti, hogy egy csillagközi térben lebegő századmilliméter méretü porszem, amelynek pozíciója $1 \mathrm{~cm}$ mértékben bizonytalanná vált, várhatóan $1 \mu \mathrm{s}$-on belül egy relatíve pontos pozícióba fog ugrani. Ha azonban a pozíció csak a méretével megegyező mértékben határozatlan, tehát az egy századmilliméternyi, akkor kb. $1 \mathrm{~s}$ időbe fog telni az újbóli lokalizáció. Tehát sehol az univerzumban nem lehet egy porszemnél nagyobb méretü test jelentősebb mértékben delokalizált a mindent kitöltő kozmikus háttérsugárzás fotonjai miatt. A dekoherencia hatását kísérletileg is bizonyították oly módon, hogy a fullerének $\left(\mathrm{C}_{60}\right)$ által létrehozott interferenciakép romlását vizsgálták a nem tökéletes vákuumban történő alkalmankénti ütközések miatt. 
1. táblázat. Lokalizációs idök $s \cdot \mathrm{cm}^{2}$ mértékegységben

\begin{tabular}{|l|c|c|c|}
\hline & $\begin{array}{c}a=10^{-5} \mathrm{~m} \\
\text { porszem }\end{array}$ & $\begin{array}{c}a=10^{-7} \mathrm{~m} \\
\text { porszem }\end{array}$ & $\begin{array}{c}a=10^{-8} \mathrm{~m} \\
\text { nagy molekula }\end{array}$ \\
\hline kozmikus háttérsugárzás & $10^{-6}$ & $10^{6}$ & $10^{12}$ \\
\hline$T=300$ K fotonok & $10^{-19}$ & $10^{-12}$ & $10^{-6}$ \\
\hline napfény (a Földön) & $10^{-21}$ & $10^{-17}$ & $10^{-17}$ \\
\hline $\begin{array}{l}\text { laborbeli vákuum } \\
\left(10^{3} \text { részecske/cm }\right.\end{array}$ ) & $10^{-23}$ & $10^{-19}$ & $10^{-30}$ \\
\hline $\begin{array}{l}\text { levegó molekulák } \\
\text { (légköri nyomáson) }\end{array}$ & $10^{-36}$ & $10^{-32}$ & \\
\hline
\end{tabular}

Az Everett-féle tárgyalásmóddal a határozatlansági reláció sem sérül, ugyanis a legutolsó mérés biztosítja az összes információt a vizsgált rendszerröl, tehát nincs korreláció a korábbi megfigyelések és az újabb megfigyelések eredményei között. Tehát amennyiben az $A$ mennyiség kétszeri meghatározása között a megfigyelő megméri a $B$ mennyiséget is (lásd a Stern-Gerlach kísérletről szóló részben a spin váltakozó irányban történő mérése), akkor a közbeiktatott mérés meg fogja szüntetni az egyértelmü megfeleltetést az A-ra vonatkozó korábbi és későbbi memóriaállapotok között. Amennyiben több megfigyelő is mérést végez ugyanazon rendszeren, majd pedig kommunikálnak és megosztják egymás között a mérés eredményeit, akkor a kommunikáció révén megvalósuló kölcsönhatás úgy vehető, hogy az korrelációt hoz létre a megfigyelők memóriakonfigurációi között. Amennyiben a második megfigyelő a kommunikációt követően, a mérési eredmények birtokában végzi el saját maga is a mérést, akkor természetesen ugyanazokat az eredményeket fogja ö maga is kapni.

\section{4. Érvek a multi-világ interpretáció mellett}

Számos olyan jelenség van, amelynek értelmezésekor a hagyományos koppenhágai interpretációt követve paradoxonokba ütközünk, melynek során látszólag fénynél gyorsabb információterjedés, nem valódi határozatlanság vagy egyéb probléma merül fel, illetve több olyan kísérlet vagy módszer került kidolgozásra, amely közvetlenül vagy közvetve érveket szolgáltat a párhuzamos univerzumok létezésére. Elsőként tekintsük mindjárt át a legújabb és talán legerősebb érveket szolgáltató kísérletet.

\subsection{Wigner barátja}

A Wigner által kigondolt gondolatkísérlet a megfigyelések objektív tulajdonságával kapcsolatban vetett fel érdekes problémát. Az elgondolás alapját Schrödinger macskája szolgáltatta, amely a mérési folyamat és a hullámfüggvény összeomlásának problematikáját célozta meg [10, 4]. Schrödinger a kvantumfizika józanésszel ellentétesnek tünő eredményei alapján azt fejtegette ugyanis, hogy amennyiben a mérést megelőzően egy rendszer nincs egyértelmüen meghatározott állapotban, hanem a lehetséges állapotok szuperpozíciójában, akkor ennek makroszkopikus rendszerekre, sőt élőlényekre is igaznak kellene lennie. Tegyük fel, hogy létrehozunk egy tökéletesen szigetelő dobozt, amelyből semmilyen módon nem kaphatunk információt, és ebben a dobozban elhelyezünk egy kvantumfizikai orosz rulett készüléket egy élő macskával. A doboz lezárása után az eszköz bizonyos időközönként fotonokat lőne egy féligáteresztő tükörre, tehát a foton $50-50 \%$ eséllyel áthalad vagy visszaverődik. A foton áthaladása müködésbe hozna egy kalapácsot, amely széttörne egy méreggel teli ampullát. Schrödinger úgy érvelt, hogy amíg a dobozt a megfigyelö ki nem nyitja, addig a macska az élö és halott állapotok szuperpozíciójában 
van, tehát egyszerre élő és halott. Wigner ezt a gondolatkísérletet használta fel arra, hogy azt továbbgondolva Von Neumann négy évtizeddel azelötti elgondolását szó szerint vegye. Neumann úgy gondolta ugyanis, hogy a hullámfüggvény összeomlása akkor következik be, amikor egy öntudattal rendelkező megfigyelö mérést végez el a kvantumfizikai rendszeren. Eszerint a Schrödinger féle kísérletben a macska sorsa nem is a doboz kinyitásakor dőlne el, hanem amikor egy öntudattal rendelkező megfigyelö tudomást szerez az eredményről. Ha például a macska doboza egy messzi ürszondán van, és azt egy automata szerkezet nyitja ki, miközben a doboz belsejéröl videofelvétel készül, akkor a macska sorsa nem dőlne el addig, amíg a jel el nem érné a Földet. Ha viszont egy ürhajóst kiküldenek a szondához, hogy élőben figyelje meg a doboz kinyitását, akkor a macska sorsa azonnal eldőlne. Ez a Wigner barátja nevü paradoxon (Wigner a Földön figyeli a felvételt, a barátja pedig a helyszínen nézi a doboz kinyitását). Természetesen az öntudattal rendelkező megfigyelők nem rendelkeznek akkora hatalommal, hogy akár az egész univerzum hullámfüggvényét egyetlen jól meghatározott állapotba tudják átvinni mindössze annak megfigyelésével, és a látszólagos paradoxon is könnyen megmagyarázható a sokvilág-interpretáció alapján. Eszerint a közelben lévő ürhajós állapota a kinyitás pillanatában összefonódik a macska állapotával, tehát egy halott macska és szomorú ürhajós, valamint egy élö macska és boldog ürhajós szuperpozíció kerül kisugárzásra a szintén korrelációba kerülő kamerarendszer által. Amikor pedig a jel eléri a földi megfigyelőt, akkor ennek a második megfigyelőnek az állapota is összefonódik a távoli rendszer állapotával. Van tehát egy időtartam, ameddig a két megfigyelő objektív valósága ellentmondásban van egymással. Amíg a jel a Föld felé halad az első megfigyelö szerint már összeomlott a macska hullámfüggvénye, a második szerint még nem. Ezt a gondolatkísérletet, vagyis ennek egy kibővített változatát nemrégen sikerült ténylegesen megvalósítani és igazolni [11] egy kísérlet során, és az eredmények alapján bizonyosan kijelenthető, hogy a különböző megfigyelők nem egyeznek meg az általuk tapasztalható valóságot illetően. Ez az ellentmondás az Everett-féle sokvilág-interpretáció alapján könnyen megmagyarázható, így az egy jelentős érv a kvantumfizika ezen értelmezése mellett.

\subsection{Az Einstein-Podolsky-Rosen (EPR) paradoxon}

Az EPR gondolatkísérlet [12] lényege, hogy amennyiben két részecske állapota egy kölcsönhatás során összefonódott, majd a részecskéket messzire eltávolítjuk egymástól és közöttük a kölcsönhatás megszünik, akkor az egyik részecske állapotát megmérve a másik részecske állapotáról azonnal információhoz jutunk, tehát annak hullámfüggvénye a távoli mérés hatására azonnal összeomlik. Ha egy másik menynyiséget mérünk meg, amelynek operátora az előző mennyiség operátorával nem felcserélhető, akkor pedig a távoli részecske ennek megfelelő állapotba fog kerülni. Ez ellentmondásban van azzal a ténnyel, hogy a részecskék között már megszünt a kölcsönhatás, valamint a mérés tényével kapcsolatos információ látszólag a fénynél gyorsabban haladva azonnal odaér a másik részecskéhez. Ha ez az összeomlás azonban nem menne azonnal végbe, akkor a két részecskén elvégzett szimultán méréssel elvileg a Heisenberg-féle határozatlansági reláció által előírt hibánál pontosabban egyszerre meg lehetne határozni a két részecske helyét és lendületét. Az egyiknél mérni kellene a helyet, a másiknál a lendületet. E paradoxon miatt Einstein meg volt győződve arról, hogy a kvantumfizika elmélete helytelen, vagy legalábbis nem teljes.

A gondolatkísérletből végül John Bell egy ténylegesen elvégezhető kísérletet dolgozott ki a 60-as években. A kísérlet a pozíció és lendület mérése helyett fotonok polarizációjának mérését foglalta magába. A polarizáció mérése ugyanis mindössze két lehetséges értéket ad, vagy áthalad a foton a polarizációs szürőn vagy nem. Amennyiben a kiválasztott polarizáció egyezik a fotonéval, akkor az áthaladás biztosan bekövetkezik, ha viszont a két polarizáció iránya egymásra merőleges, akkor a foton visszaverődik. Bármely más relatív $\theta$ szög esetén az áthaladás valószínüsége $\cos ^{2} \theta$. A kísérletet Aspect és 
kollégái hajtották végre [13] a 80-as évek elején. Olyan fotonokat használtak, amelyek egy reakció eredményeként ellentétes irányban és megegyező polarizációval kerültek kibocsátásra, tehát összefonódott állapotokkal rendelkeztek. Ilyenkor a fotonok polarizációjának pontos iránya nem ismert a megfigyelö számára a mérést megelözően, azonban a polarizációs szűrőn való áthaladáskor vagy visszaverődéskor a vizsgált foton polarizációja a szürővel megegyező, illetve arra merőleges irányba ugrik be. Ez azonban a nem mért foton polarizációját is azonnal beállítja ugyanebbe az irányba. Ezt úgy bizonyították kísérletileg, hogy mindkét foton polarizációját megmérték egyszerre két egymáshoz képest változó szögben beállított polarizációs szürő segítségével. A fotonok áthaladási valószínüségét vizsgálva a szürők relatív szögének függvényében sikerült bizonyítaniuk, hogy a Bell-féle egyenlötlenség teljesül, tehát a fotonok látszólag azonnal tudomást szereznek a másik fotonon végzett mérésröl.

A látszólagos kvantum-nonlokalitás miatt bekövetkező paradoxon feloldására itt is felhasználható a sokvilág-interpretáció $[7,14]$. Az egyes mérések helyein ugyanis a lehetséges eredményekhez tartozó állapotok szuperpozíciója alakul ki, amelyekkel kapcsolatos információ aztán a fénynél lassabban terjed egymás felé. A szuperpozíciók úgy kombinálódnak, hogy az egymással konzisztens elemek kerülnek korrelációba egymással. Tehát a mérési eredmények összevetésekor azokban nem jelentkezik ellentmondás a fotonok összefonódásának tényét illetően. Ezt úgy kell elképzelni, hogy a mérés elvégzésének pillanatában az összes lehetséges mérési eredménynek megfelelő klasszikus világ jelenik meg mindkét helyen, amelyek egyfajta szálakként terjednek egymás felé [4]. Amikor a két mérési hely felöl terjedő szálak találkoznak egymással, akkor automatikusan az egymással logikai kapcsolatban, tehát korrelációban lévő szálak fognak összekapcsolódni, és a különböző összekapcsolódási változatokban helyet foglaló megfigyelök nem fognak egymásról tudomást szerezni. Tehát a kísérlet mindegyik klasszikusnak tekinthető világban mindkét megfigyelő számára csak látszólag eredményezi az információ fénynél gyorsabban történő terjedését.

\subsection{A kvantumszámítógép}

A kvantumszámítógép mủködése a sokvilág-interpretáció szerint abban áll, hogy a párhuzamos világok felhasználásával egyszerre óriási számú műveletet tud elvégezni $[4,15,16]$. Ha például nagy prímszámok összeszorzásáról van szó, akkor a számjegyek számának növelésével az eredmény kiszámításához szükséges idő mindössze lineárisan növekszik. Ha azonban két ismeretlen prímszám szorzata esetén szeretnénk a prímtényezőket megtalálni, akkor a számjegyek számának növelésével exponenciálisan növekszik a számítási idő. Ugyanis erre csak egyetlen mód van, sorban el kell osztogatni a számot az egyre növekvő prímszámokkal egészen addig, amíg a müvelet egész értéket nem ad. Itt jelenik meg a kvantumszámítógépnek az az előnye, hogy ezeket a müveleteket egyszerre képes elvégezni. A számítógép különböző változatai az egyszerre létező párhuzamos világokban ugyanis egymástól függetlenül tudják a különböző müveleteket végrehajtani, majd amikor az egyik világban megszületik az eredmény, arról a számítógép összes változata értesül. A másik jelentős különbség a kvantumszámítógép és a hagyományos számítógépek között, hogy a hagyományos számítógépek biteken végeznek müveleteket, amelyek értéke 0 vagy 1 lehet. Ezzel szemben a kvantumszámítógépek qubiteken vagyis kvantum biteken végeznek müveleteket, amelyek a 0 és 1 tetszőleges szuperpozíciójában lehetnek. Így aztán a kvantumszámítógépek természetes módon sokkal alkalmasabbak a természetben végbemenő kvantumfizikai folyamatok modellezésére. Az IBM 2020 szeptemberében hozta létre jelenlegi legnagyobb kvantumszámítógépét, amely 65 qubitet tartalmaz [17], és 2023-ra 1000 qubitet tartalmazó rendszer megvalósítását tervezik. Addig is az elkövetkező években 127 és 433 qubittel rendelkező számítógépeket fognak megépíteni. Ezzel szemben a Google 2019-ben egy 53 qubitet tartalmazó kvantumszámítógéppel olyan számítást hajtott végre 200 másodperc alatt [18], amely a leggyorsabb szuperszámítógép számára is 2,5 
napig tartana (eredetileg 10 ezer évet publikáltak, de ezt az IBM cáfolta). Nagy tehát a verseny a két cég között, és mindkettő 1 millió qubitet tartalmazó kvantumszámítógépet ígér 10 éven belül. Az ilyen számítógépek megvalósíthatósága és müködése tehát jelenleg már nem kérdés, ahogyan az sem, hogy bizonyos alkalmasan választott feladatok esetén a közeljövőben messze meg fogják haladni a hagyományos számítógépek teljesítményét. Felmerül azonban a kérdés, hogy honnan eredne ez az óriási mértékben megnövekedett számítási kapacitás, ha az Everett-féle sokvilág-interpretáció nem helyes, és nem léteznek a párhuzamos világok?

\subsection{Kölcsönhatás nélküli mérés}

Bármennyire is furcsának tünik, a párhuzamos világok létezése lehetőséget biztosít arra, hogy úgy végezzünk mérést egy rendszeren, hogy azt egyáltalán nem befolyásoljuk [4]. Az alapvető eljárás ElitzurVaidman kísérletként ismert, melynek idővel egyre bonyolultabb és egyre tökéletesebb változatait is végrehajtották. A kísérlet alapja egy Mach-Zehnder interferométer, amely a részecske- és hullámtulajdonság megkülönböztetésére szolgáló eszköz (2. ábra bal oldala). Az $O$ pontból egy fénysugár érkezik, amely az $A$ féligáteresztő tükörre vetődik, majd a kettéválás után a $B$ és $C$ tükrökről visszaverődve a $D$ féligáteresztő tükörnél újra egyesül. Itt újból a fénysugár fele halad át és fele verödik vissza, és ezek végül elérik az $E$ és $F$ detektorokat. Ha a fotonok klasszikus részecskék mintájára viselkednének, akkor minden lehetséges útvonalat a fotonok egynegyede választaná, és a detektorokra fele-fele arányban érkeznének a fotonok. A valóságban azonban a fotonok akár egyesével is hullámtulajdonságot mutatnak, amely akkor jelentkezik jól láthatóan, ha a távolságokat úgy választjuk meg, hogy az $A B D E$ és $A C D E$ távolságok egyenlők maradnak, az $A B D F$ és $A C D F$ távolságok viszont egy fél hullámhossznyi mértékben különböznek egymástól. Ekkor az $F$ detektorba nem érkeznek fotonok, mert a hullámok destruktív interferencia folytán semlegesítik egymást. Ha most elhelyezünk egy tárgyat az $A$ és $C$ közé, akkor az a fotonok felének gátolja az áthaladását, és megszünik az interferencia (2. ábra jobb oldal). Tehát újra fele-fele arányban érkeznek a fotonok az $E$ és $F$ detektorokba.
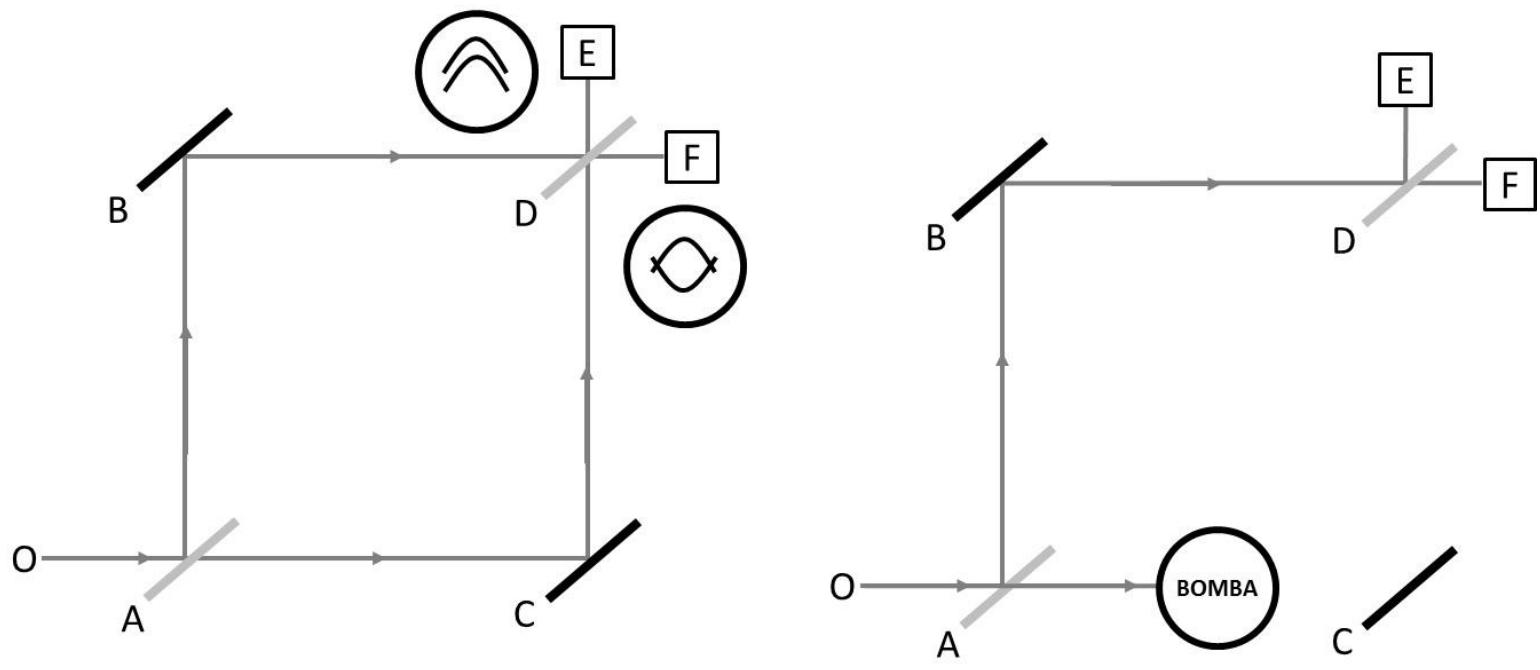

2.ábra. Mach-Zehnder interferométer bomba nélkül (bal)és bombával (jobb)

Legyen a fotonok útját blokkoló tárgy egy detektorral üzemeltetett bomba. Ezzel az elrendezéssel lehetőség nyílik a bomba ottlétének vizsgálatára a bomba felrobbantása nélkül. Ha ugyanis nincs ott a 
bomba, akkor a foton mindig az $E$ detektorhoz érkezik, és az $F$ detektor sosem jelez fotont. Ha viszont ott van a bomba, akkor a foton $50 \%$ eséllyel abba az irányba halad, és felrobbantja azt. Ha viszont a foton a másik irányba halad tovább az $A$ féligáteresztő tükörről visszaverődve, akkor további $50-50 \%$ lesz az esélye annak, hogy az $E$ vagy az $F$ detektorra érkezik. Minden egyes foton tehát $25 \%$ eséllyel úgy figyelmeztethet minket a bomba jelenlétéről, hogy az nem robban fel. Ez úgy magyarázható, hogy amikor a foton eléri az $A$ féligáteresztő tükröt, akkor lényegében két párhuzamos világ jön létre. Az egyikben a foton továbbhalad a $C$ tükör felé, a másikban pedig visszaverődik a $B$ tükör felé. Ezek a világok mindaddig kölcsönhatásban vannak, amíg az egyikben meg nem történik a foton elnyelése. Ha tehát a mi világunkban a foton a $B$ tükör felé halad, a $C$ tükör felé pedig szabad az út, akkor kölcsönhatásban marad a párhuzamos világbeli megfelelőjével, és interferencia következik be. Ha azonban a másik világban a $C$ tükör felé haladó fotont a bomba detektora elnyeli, akkor a dekoherencia miatt megszünik a két világ közötti kapcsolat, és a foton részecskeként viselkedve halad tovább, nem lesz interferencia. Ezzel a módszerrel tehát bizonyos értelemben információ nyerhető egy párhuzamos világból, amelyben a bomba ténylegesen felrobban. Természetesen a $25-50 \%$ arány a sikeres figyelmeztetés és a bomba felrobbanása között nem tủnik túl kecsegtetőnek, de a módszer továbbfejlesztett változataival a siker aránya sokszorosára növelhetö.

Az említett elrendezés mellet olyan is lehetséges, amelyben különböző időpontokban elindult fotonok közötti interferencia figyelhető meg [4]. Ekkor egy olyan világból származó információt használunk fel, amely bizonyos értelemben elörébb jár az időben a miénkhez képest.

A kölcsönhatás nélküli mérömüszerek tényleges mindennapi felhasználása is minden bizonnyal meg fog valósulni a közeljövőben. Elképzelhető ugyanis egy olyan müködő röntgenkészülék, amelynél a kép létrehozásához felhasznált fotonok túlnyomó része a valóságban nem is haladt át az ember testén [19].

\subsection{Nagypapa paradoxon}

Az általános relativitáselmélet elvileg nem tiltja zárt időszerü hurkok létrejöttét [20], és így az időutazást, de a múltba elvileg is csak az időgép megépítésének pillanatáig lehetne visszamenni. Sok olyan történet létezik, amelyben az időutazók visszamennek a múltba, hogy megváltoztassák azt [21], majd a jelenbe visszaérve egy teljesen más világban találják magukat. Az ilyenkor megemlített paradoxon úgy szól, hogy mi van akkor, ha az időutazó olyan események sorozatát indítja el a múltban, amely végső soron a saját születésének meghiúsulásához vezet? Általában a nagypapa meggyilkolását veszik példának, mégpedig az apa megszületését megelözően. Amennyiben egyetlen világvonal létezik, akkor ez értelemszerüen tényleg paradoxonhoz vezetne, hiszen ha nem született meg, akkor hogyan tud mégis visszamenni az időben. Egyetlen világvonal esetében a paradoxon feloldásához nagyon komoly matematikai erőfeszítésekre [22] van szükség, és a szabad akarat problematikája sem egyértelmü, ugyanis a megoldás feltételeket szabna az időutazó által végrehajtható cselekvésekre, és azok eredményére. Ilyen feltételek ismeretében kérdéses lenne, hogy egyáltalán érdemesnek látná-e az illető az időgép megépítését. A sokvilág-interpretáció szempontjából nézve azonban semmilyen korlátozásra nincs szükség, az időutazó mindössze olyan új világvonalakat hozna létre, vagy lépne rá azokra, amelyek eltérnek a saját addigi memóriájában meglévő idővonaltól. Tehát ha valaki tényleg visszamenne az időben, hogy megölje a nagyapját, akkor egy olyan idővonal leágazást hozna létre, amelyben ő nem születik meg, így a jelenbe visszautazva egy olyan világban találná magát, amelyben sosem létezett [15]. Nem fog a tettének hatására fokozatosan kitörlődni a kozmikus valóságból, mint a „Vissza a jövőbe” címü filmben a föszereplö, amikor úgy tünt, hogy a szülei mégsem jönnek össze, bár minden bizonnyal megérdemelné. 


\subsection{Kvantumöngyilkosság}

Az Everett-féle sokvilág-interpretáció bizonyításának legbiztosabb és egyben legdrasztikusabb módja, ha valaki behelyettesíti magát Schrödinger macskájának helyébe, és megpróbál öngyilkosságot elkövetni. Ezzel párhuzamosan van egy biztos módja annak is, hogy gyorsan meggazdagodjon [4], mégpedig úgy hogy vásárol egy lottószelvényt, majd pedig ráköti magát egy olyan gépre, amely azonnal megöli, ha nem nyert. Ha valaki biztos benne, hogy szinte végtelen számú párhuzamos univerzum létezik, akkor mindenképpen nagyon sok univerzumnak kell lennie, amelyben nem hal meg és gazdag is lesz. A bizonyítás kedvéért elvégzett kísérletben képzeljünk el egy olyan fegyvert, amely egy két egyenlő valószínűségü kimenetelt eredményező mérés (pl. egy foton áthaladása vagy visszaverődése, vagy egy elektron spinjének pozitív vagy negatív értéke) alapján éles- vagy vaktöltényeket lő ki. A fegyver müködését kívülről figyelve meghatározott időnként véletlenszerüen éles- és vaktöltények kilövését tapasztalnánk. A fegyver elé beállva azonban kizárólag vaktöltényeket lőne ki egymás után. Kilépve a fegyver elől, az újra lőne ki éles lőszereket is véletlenszerü sorrendben. Vissza beállva a fegyver elé, az megint csak vaktöltényeket lőne ki. Egyre hosszabb időt eltöltve a fegyver elött, egyre nagyobb bizonyossággal tudná az illető saját magának bebizonyítani, hogy a párhuzamos univerzumok valóban léteznek. Ezt úgy lehet elképzelni, hogy az illető a saját állapotával kapcsolatos memóriakonfiguráció meghatározása céljából folyamatosan megfigyelést végez a saját testén. Minden egyes orosz rulett sorsolás után a testének két lehetséges állapota lehetséges, élet vagy halál. A sokvilág-interpretáció szerint mindkét állapot egyforma valószínüséggel realizálódik. Annak a valószínüsége viszont, hogy egy ember a saját testének megfigyelése során a halott állapotot tapasztalja nulla, hiszen ez ellentmondás. A személyes élmény tehát minden esetben a szerencsés kimenetel lesz. Ehhez természetesen az lenne szükséges, hogy a fegyver azonnal és 100 százalékos valószínüséggel megölje az embert, valamint teljesen megbízhatóan müködjön. Egy idő után ugyanis egy nem halálos sérülésnek vagy a fegyver meghibásodásának nagyobb lenne a valószínüsége, mint a kvantum orosz rulett által eredményezett szerencsés kimenetelnek. További probléma, hogy ezzel mindössze magának tudja bebizonyítani a párhuzamos világok létezését, ugyanis a külső megfigyelők nagyon rövid idő elteltével azt tapasztalnák, hogy egyszerüen lelőtte magát. David Lewis filozófus úgy gondolta [23], hogy az emberek mindennapi balesetek során bekövetkezö halála is ilyen véletlenszerú események sorozatának következménye. Tehát az emberek akaratukon kívül egy folyamatos kvantum orosz rulett játéknak vannak kitéve, valamilyen valószínüséggel bármikor bekövetkezhet egy tragikus esemény. Sőt, akár a természetes elhalálozási okot, pl. egy ér elzáródását is lehet ilyen véletlenszerü eseménynek tekinteni [4]. Ha például valaki átszalad az úton és elüti egy teherautó, akkor az események nagyon apró változása is eredményezheti azt, hogy ez mégse történjen meg. Egy extra foton rávetülése a retinára vezethet a történések olyan sorozatához, hogy a baleset ne következzen végül be. Még az ütközés bekövetkeztével is lehetséges a molekulák olyan szerencsés mozgása, hogy az illető ne haljon meg.

Ezt többen is úgy értelmezték, hogy az öntudat halhatatlan, azt semmilyen módon nem lehet kioltani, megszüntetni $[24,25]$. Ezt az elképzelést kvantumhalhatatlanságnak nevezik. A történet szépséghibája, hogy az elképzelés szerint a fentebb említett baleset során bármilyen súlyosságú, de az élettel még öszszeegyeztethető maradandó sérülés bekövetkezhet, így aztán a feltételezett örök élet önmagában mégsem ad okot a felhőtlen örömre. David Lewis ezért attól félt, hogy a test folyamatos degradálódása ellenére hiába várja majd a megváltó halált, hiszen ha a hullámfüggvény tényleg nem omlik össze, annak egyenes következménye a végtelen élet. David Deutsch ezzel szemben úgy nyilatkozott, hogy nem fél ettől a következménytől, ugyanis amennyiben tényleg hosszú életet fog élni, az nagy valószínúséggel az orvosi technológia fejlődése miatt lesz, és ez lehetővé teszi majd a megfelelő életminőséget [4]. Annak ugyanis, hogy káprázatos orvosi fejlődések történnek sokkal nagyobb a valószínüsége, mint annak, hogy 
minden másodpercben a Brown mozgás valamilyen konspiráció folyományaként életben tartsa az agyát egy olyan testben, amely valójában szinte megszünt müködni. Max Tegmark úgy gondolja, hogy bár a hirtelen halál nem lehetséges, végül csak olyan idővonalak lesznek lehetségesek, amelyeken az öntudata szépen apránként kialszik, miközben gondolatai egyre lassulnak. A legextrémebb elképzelés ezzel a témával kapcsolatban Frank J. Tipler nevéhez füződik [26], aki úgy gondolja, hogy a távoli jövőben a számítási kapacitás elegendő lesz univerzumok szimulációjához, bennük a valaha élt összes emberrel, sőt minden olyan emberrel, aki valaha élhetett volna. Amennyiben más lehetőség már nem marad, akkor talán majd ebben a virtuális valóságban él tovább az öntudatunk, de akár az is lehetséges, hogy már most is egy ilyen világban élünk. A szimuláció megfelelő minősége esetén ugyanis nincs mód számunkra, hogy azt megkülönböztessük a valóságtól, sőt talán nincs is nagyon értelme annak, hogy különbséget tegyünk. Mindenesetre az a tény, hogy a tér és idő is kvantáltnak tünik, valamint a fizikai mennyiségek sem ténylegesen folytonos értékủek, ahhoz vezet, hogy a jelenlegi multiverzumunk futtatásához véges számítási kapacitás kell. Ez még akkor is igaz, ha különbözö kezdeti feltételekkel minden lehetséges multiverzumot számításba veszünk, amelyek száma a húrelméletből levezetett kozmikus tájkép szerint $10^{500}$ nagyságrendü [27]. Ez nagy szám, de nem végtelen, tehát elviekben futtatható lenne a világmindenség egy gigantikus kvantumszámítógépen.

\section{5. Összefoglalás}

A cikk kísérletet tesz arra, hogy a kvantumfizikában már több mint egy évszázada meglévő dilemmát érzékeltesse, amelynek lényege a mérés folyamatának problematikáját illeti. Az eredeti koppenhágai elképzelés szerint a hullámfüggvény összeomlik a mérés végrehajtásakor, és a mérés lehetséges értékei közül csak egyetlen egy valósul meg. A cikkben említett paradoxonok és egyéb jelenségek, logikai problémák alapján viszont ez nem tünik a kvantumfizika helyes interpretációjának. Az utóbbi évtizedek során egyre inkább teret nyert az oxfordi interpretáció, amely az Everett-féle sokvilág-interpretáció alapján jött létre, és amelynek követői végső soron, néhány apró változtatástól eltekintve, mind ezt az elképzelést tartják helyesnek, logikailag megalapozottnak és esztétikailag kielégítőnek. Mint láttuk, a technológia fejlödésével számos olyan kísérlet elvégezhető, és számos olyan eszköz megépíthető, amelyekkel a kvantumfizikának a valóságról alkotott klasszikus elképzelésekkel meredek ellentétben álló jelenségei valósíthatók meg. Ez a folyamat a jövőre nézve valószínűleg csak egyre drámaibb lesz, így aztán várhatóan tovább fog növekedni azok száma, akik a sokvilág-interpretáció mellet teszik le voksukat.

\section{Irodalom}

[1] Nagy, K.: Kvantummechanika, Nemzeti Tankönyvkiadó, Budapest, 1978, ISBN 963185610-0

[2] Planck, M.: The theory of heat radiation, P. Blakiston's Son \& Co., Philadelphia, 1914, OL 7154661M, https://archive.org/details/theoryofheatradi00planrich

[3] Davisson, C., Germer, L. H.: The scattering of electrons by a single crystal of nickel, Nature 119, (1927) pp. 558-560. https://doi.org/10.1038/119558a

[4] Bruce, C.: Schrödinger's rabbits - the many worlds of quantum, Joseph Henry Press, Washington, DC, 2004, ISBN 10: 0309090512/ISBN 13: 9780309090513

[5] Sakurai, J. J.: Modern quantum mechanics revised edition, Addison-Wesley Publishing Company Inc., 1994, ISBN 0-201-53929-2

[6] Gerlach, W., Stern, O.: Der experimentelle Nachweis der Richtungsquantelung im Magnetfeld, Zeitschrift für Physik, 9 (1): (1922) pp. 349-352. Bibcode:1922ZPhy....9..349G https://doi.org/10.1007/BF01326983 
[7] Everett III., H.: Relative state formulation of quantum mechanics, Reviews of Modern Physics, Vol. 29 (3), (1957) pp. 454-462. https://doi.org/10.1103/RevModPhys.29.454

[8] Everett III., H.: The Everett interpretation of quantum mechanics - Collected works 1955-1980 with commentary, Princeton University Press, 2012, ISBN 978-0-691-14507-5

[9] Joos, E.: Elements of environmental decoherence in P. Blanchard, D. Giulini, E. Joos, C. Kiefer, and I.-O. Stamatescu (eds), Decoherence: Theoretical, experimental, and conceptual programs, 1999, Heidelberg, Germany: Spinger.

[10] Wigner, W. E., in The scientist speculates, edited by I. Good, 1961, pp. 284-302

[11] Proietti, M., Pickston, A., Graffitti, F, et al.: Experimental test of local observer-independence, Science Advances, 5:eaaw9832. https://doi.org/10.1126/sciadv.aaw9832

[12] Einstein, A., Podolsky, B., and Rosen, N.: Can quantum-mechanical description of physical reality be considered complete? Phys. Rev., 1935, 47, 777. https://doi.org/10.1103/PhysRev.47.777

[13] Aspect, A., Grangier, P., Roger, G.: Experimental tests of relativistic local theories via Bell's theorem, Phys. Rev. Lett., 47 (7), (1981) pp. 460-463. https://doi.org/10.1103/PhysRevLett.47.460

[14] Tipler, F. J.: Nonlocality as evidence for a multiverse cosmology, Modern Physics Letters A, 2010, 27 (4). https://doi.org/10.1142/S0217732312500198

[15] Gribbin, J.: In search of the multiverse - Parallel worlds, hidden dimensions, and the ultimate quest for the frontiers of reality, John Wiley \& Sons, Inc., 2009, Hoboken, New Jersey, ISBN 978-0-470-61352-8

[16] Deutsch, D.: The fabric of reality, Penguin Books, 1997, New York, ISBN 0-7139-9061-9

[17] https://www.sciencemag.org/news/2020/09/ibm-promises-1000-qubit-quantum-computer-milestone-2023

[18] Arute, F., Arya, K., et al.: Quantum supremacy using a programmable superconducting processor, Nature, 574, (2019) pp. 505-510.

[19] Kent, A., Wallace, D.: Quantum interrogation and the safer X-ray, arXiv:quant-ph/0102118

[20] Davies, P.: How to build a time machine, Penguin Putnam Inc., 2003, New York, ISBN 014-2001-864

[21] Drummer, J. P.: A Trianon-küldetés, A szerző saját kiadása, 2019, Budapest, ISBN 978-615-006774-2

[22] Tobar, G., Costa, F.: Reversible dynamics with closed time-like curves and freedom of choice, Classical and Quantum Gravity, 2020, 37 (20): 205011, https://doi.org/10.1088/1361-6382/aba4bc

[23] Lewis, D.: How many lives has Schrodinger's cat? Australasian Journal of Philosophy, 82 (1): (2004) pp. 3-22. https://doi.org/10.1080/713659799

[24] Higgo, J.: Does the 'many-worlds' interpretation of quantum mechanics imply immortality? https://web.archive.org/web/20070827000748/http://www.higgo.com/quantum/qti.htm

[25] Tegmark, M.: The Universes of Max Tegmark, https://space.mit.edu/home/tegmark/quantum.html

[26] Tipler, F.-J.: The physics of immortality - Modern cosmology, God and the resurrection of the dead, Anchor Books Doubleday, 1995, New York, ISBN 0-385-46799-0

[27] Vilenkin, A.: Many worlds in one - The search for other universes, Hill and Wang, 2006, New York, ISBN 978-0-8090-6722-0 